\title{
Agar media for isolation of Neonectria ditissima from symptomatic and asymptomatic apple tissues and production of infective conidia
}

\author{
N.T. Amponsah ${ }^{1}$, M. Walter ${ }^{1}$ and R.W.A. Scheper ${ }^{2}$ \\ ${ }^{1}$ The New Zealand Institute for Plant E Food Research Limited (PFR), Old Mill Road, \\ RD 3 Motueka 7198, New Zealand \\ ${ }^{2}$ PFR, Private Bag 1401, Havelock North 4130, New Zealand \\ Corresponding author: nicholas.amponsah@plantandfood.co.nz
}

\begin{abstract}
European canker pathogen, caused by the fungus Neonectria ditissima, could not be isolated when infected woody tissues were plated directly onto potato dextrose agar (PDA), malt extract agar (MEA) or acidified PDA ( $\mathrm{pH} 4.5$ ). However, the alternative media, water agar (WA) and apple sap-amended water agar (ASAWA), were successfully used to isolate the pathogen. In the preparation of ASAWA, green shoots of 1-year-old fresh 'Scilate' apple were frozen overnight then allowed to thaw. The tissues were then centrifuged and the sap collected to prepare the medium. Neonectria ditissima could be isolated from both symptomatic and asymptomatic apple tissues on both WA and ASAWA. Both media supported the production of large numbers of conidia in vitro, with more conidia being produced on ASAWA than on WA. The conidia produced in vitro had morphological characteristics and pathogenicity similar to those produced in the field.
\end{abstract}

Keywords Neonectria ditissima, apple sap, 'Scilate', 'Braeburn' 'Royal Gala', asymptomatic, conidia, isolation, pathogen.

\section{INTRODUCTION}

European canker (EC), caused by the fungus Neonectria ditissima, can result in death of apple buds, shoots, spurs and branches. Sporulation, spore dispersal and infection of $N$. ditissima are enhanced by rainfall (McCracken et al. 2003; Beresford \& Kim 2013). Because canker symptoms in apple orchards may also be caused by other fungal or bacterial pathogens, diagnosis of European canker usually relies on the presence of white sporodochia or reddish-brown perithecia formed in association with the infected tissues. Because sporulation is not always present within canker lesions, the pathogen has to be isolated into axenic culture for identification. However, the fungus is difficult to isolate from cankers (Anagnostakis \& Ferrandino 1998). There are no selective media for the isolation of $N$. ditissima from woody tissues and when general media such as potato dextrose agar (PDA), malt extract agar (MEA) and acidified PDA have been used, a large number of other fungi grow from the tissue. The only published method for $N$. ditissima isolation from woody trunk lesions is baiting using 'Granny Smith' apples (Anagnostakis \& Ferrandino 1998).

The aims of this research were to (i) develop an alternative method for fast and easy isolation 
of $N$. ditissima from both symptomatic and asymptomatic woody tissues, (ii) induce in vitro production of conidia and (iii) determine the pathogenicity of the conidia produced in vitro.

\section{MATERIALS AND METHODS}

\section{Apple sap and media preparation}

Apple sap was extracted by freezing overnight cut pieces $(\sim 7 \mathrm{~cm})$ of green shoots of 1-yearold fresh 'Scilate' apple. After thawing, five to six shoot pieces were put into a $50-\mathrm{ml}$ Falcon tube and centrifuged at $2688 \times \mathrm{g}$ for $10 \mathrm{~min}$. The sap obtained was then pipetted and sterilised by filtering through a MILLEX ${ }^{\oplus}$ GP filter unit of pore size $0.22 \mu \mathrm{m}$. The resulting sap filtrate was stored in the refrigerator at $4^{\circ} \mathrm{C}$ for up to 4 weeks before use. Water agar (WA) was prepared by suspending $15 \mathrm{~g}$ of dehydrated agar (Fisher Scientific, Mexico) in 1 litre distilled water, autoclaving and then pouring into Petri dishes. To prepare the apple sap-amended water agar (ASAWA), $2 \mathrm{ml}$ of the sap extract was pipetted into 1 litre autoclaved molten WA at $50^{\circ} \mathrm{C}$, before pouring into Petri dishes. Other media such as PDA (OXOID Ltd, Basingstoke, Hampshire England), acidified PDA (adjusted to pH 4.5 using hydrochloric acid and sodium hydroxide - BDH Chemicals Ltd, Poole, England) and MEA (Merck KGaA, Darmstadt, Germany) were all prepared according to the manufacturers' recommendations.

\section{Isolation of $N$. ditissima from woody tissues}

The success rates of $N$. ditissima isolations from infected and non-infected woody tissues onto WA and ASAWA were compared with those onto the three (PDA, acidified PDA and MEA) general media. Ten 'Scilate', 'Braeburn' and 'Royal Gala' shoot pieces $(18-20 \mathrm{~cm})$, with either a single or multiple (2-5) necrotic cankered lesions, were collected from orchard blocks, taken to the laboratory and surface sterilised in 70\% alcohol for $1 \mathrm{~min}$ and then rinsed under tap water. After air drying the shoots under a laminar flow cabinet, smaller pieces $\left(<5 \mathrm{~mm}^{2}\right)$ of tissue were aseptically excised from the edges of the lesions and the cut pieces were placed cut surface down onto each of the media. There were two replicate plates for each cultivar and medium type, and each plate contained 10 pieces of excised tissue. The plates were arranged in a completely randomised design (CRD) and incubated at $20^{\circ} \mathrm{C}$ for $2-3$ weeks under three white fluorescent (PHILIPS TLD 58W/840) lights bank with 16:8 h light:dark. Fungal morphology and formations of sporodochia were examined using a compound microscope $(\times 100)$. Sporodochia-forming fungal colonies were aseptically sub-cultured onto PDA and incubated under a light bank with 16:8 h light:dark as described above, for identification based on colony growth morphology and colour characteristics. The complete experiment was repeated after 1 month.

To identify putative symptomless infections of $N$. ditissima and other endophytes in apple trees, another 10 'Scilate', 'Braeburn' and 'Royal Gala' shoot pieces $(18-20 \mathrm{~cm})$ with no lesions were collected and processed for pathogen isolation and identification as described above.

\section{In vitro conidia production}

The $N$. ditissima isolates used to determine whether WA and ASAWA were suitable media for conidial production are shown in Table 1 . The ASAWA medium for conidia production was slightly modified from the original by adding $10 \mathrm{ml}$ of sap extract to 1 litre of WA (was previously $2 \mathrm{ml}$ ). For each isolate, mycelial discs (5 $\mathrm{mm}$ in diameter) were cut from a rapidly growing colony, put agar side down onto the ASAWA and WA plates, and then incubated at $20^{\circ} \mathrm{C}$ under a light bank with $16: 8 \mathrm{~h}$ light:dark for 2 weeks. In all, there were four replicate ASAWA and WA plates per isolate and plates were laid out in a completely randomised design (CRD). To determine the number of conidia produced, each plate was flooded with $10 \mathrm{ml}$ of sterile water, and shaken slightly to release conidia from sporodochia. The concentration of conidia in each suspension was counted using a haemocytometer ((Hawksley counting chamber BN15 8TN, UK) under a compound microscope (Olympus ${ }^{\circledR}$ BX51) at $\times 100$ magnification.

\section{Pathogenicity of conidia produced in vitro}

The pathogenicity of conidia produced in vitro on ASAWA and WA were compared with those of 
field conidia. The in vitro conidial suspension for the inoculation was prepared by mixing conidial suspensions obtained from 14 different isolates (Table 1). The field inoculum was prepared from cankers collected from an orchard block in Motueka. Sporodochia with conidia were picked off the cankers with a sterile scalpel and suspended in sterile distilled water. All spore suspensions were adjusted to a standard concentration of $1.5 \times 10^{4}$ conidia $/ \mathrm{ml}$. Inoculation was conducted on eight 'Braeburn' trees in a research orchard in Riwaka. For each tree, nine 2-year-old shoots were randomly selected and portions of the bark filed to create wounds. There were two 5-mm rasp wounds approximately $5-7 \mathrm{~cm}$ apart per shoot. The wounds were brush-inoculated with one of the three conidial suspensions produced either in vitro on ASAWA, on WA or from field-collected cankers. Each inoculum suspension was applied to six wounds ( 2 wounds per shoot $\times 3$ shoots). Each tree served as a replicate.

Disease incidence was assessed 12 weeks after inoculation and from 16-24 weeks, lesion lengths were measured using a digital calliper (Mitutoyo, U.K Ltd). After 24 weeks, the infected shoots were cut for pathogen re-isolation to confirm that $N$. ditissima was associated with the observed symptoms.

\section{Statistical analyses}

Data for all experiments were analysed by analysis of variance (ANOVA) using GENSTAT 14 (Lawes Agricultural Trust, Rothamsted Experimental Station, UK) to determine the significance of treatment effects. Means were separated according to Fisher's protected least significance difference (LSD) test.

\section{RESULTS}

In vitro conidial production and pathogenicity With the exception of isolate ICMP 13255, all isolates produced sporodochia on either ASAWA or WA, although the numbers of conidia produced differed significantly $(\mathrm{P}<0.05)$ between isolates (Table 1). Significantly more conidia were produced on ASAWA than on WA $(\mathrm{P}<0.001)$. The media effect was also significant $(\mathrm{P}<0.001$; LSD 2.8 ), as well as the media $\times$ isolate interaction
$(\mathrm{P}<0.001 ;$ LSD 11.1). Overall, the sporodochia formed on ASAWA were more numerous and larger than those produced on WA. Inoculum produced from both media consisted of a mixture of conidia with single or multiple septa, although the conidia produced on ASAWA were predominantly multi-septate. In general, the shape and sizes of the conidia produced in vitro (Figure 1) were not different from those obtained directly from several canker lesions taken from the field (data not shown).

When the conidia produced in vitro on ASAWA and WA or conidia from field cankers were compared for pathogenicity, there were no lesions on rasp wounds inoculated with conidia obtained from field cankers 12 weeks after inoculation. Lesions were observed only on rasp wounds inoculated with the conidia produced in vitro on ASAWA and WA. However, by 20 weeks

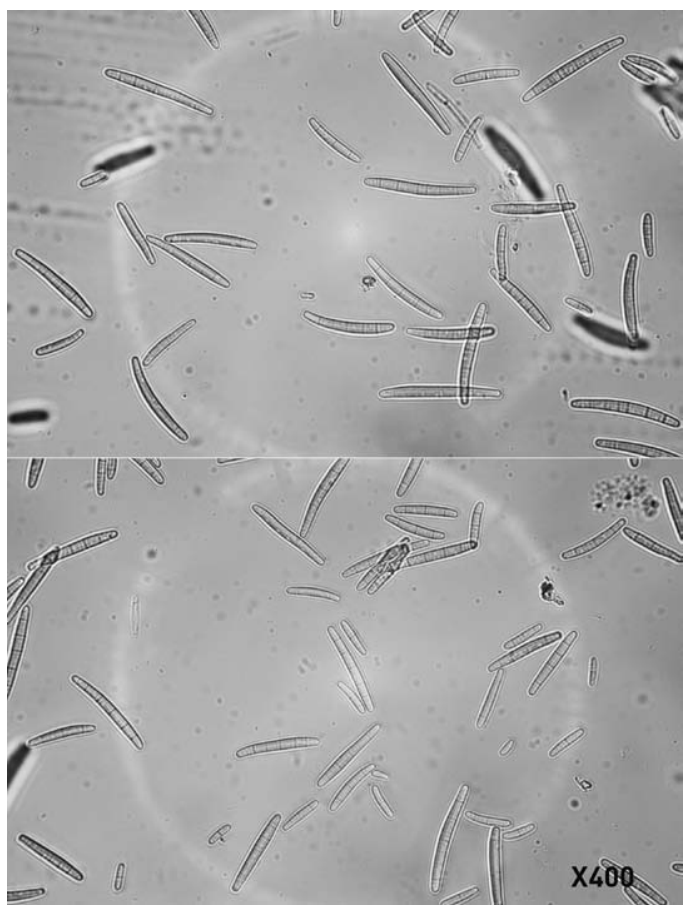

Figure 1 Neonectria ditissima conidia types showing single and multiple septations and different length and size characteristics. The sample was taken from (top) field isolations and (bottom) in vitro production on apple sap amended water agar. 
after inoculation lesions were present on all raspinoculated wounds, irrespective of inoculum source (Figure 2a). Lesion lengths measured at 16 and up to 24 weeks after inoculation did not differ $(\mathrm{P}>0.05)$ between the three inoculum sources (Figure $2 \mathrm{~b}$ ). Pathogen re-isolations onto ASAWA confirmed that $N$. ditissima could be re-isolated from the inoculated shoots.

\section{Isolation of $N$. ditissima from woody tissues}

Isolations from woody tissues onto PDA, acidified PDA ( $\mathrm{pH} 4.5)$ and MEA did not yield any colonies of $N$. ditissima, but did yield species of Neofusicoccum, Diplodia, Phomopsis, Fusarium, Alternaria, Epicoccum and Penicillium. These fungi were isolated from both symptomatic and symptomless tissues. Isolations from woody tissues onto the ASAWA and WA resulted in the production of fungal mycelia that produced N. ditissima sporodochia after 2 weeks (Figure 3 ). The repeated experiment showed a similar pattern of isolation from the excised tissues onto the respective media and so the data were combined for analysis. Of the 20 pieces, ten, four and six 'Scilate', 'Braeburn' and 'Royal Gala', respectively, yielded mycelia and sporodochia on ASAWA, whereas six, four and two pieces from 'Scilate, 'Braeburn' and 'Royal Gala', respectively, yielded mycelia and sporodochia on WA. Four and six pieces of the tissues taken from the ten symptomless 'Scilate' and 'Royal Gala', respectively also yielded mycelia and sporodochia on ASAWA and none on WA (Table 2). Other sporodochiaforming colonies also present were identified as Fusarium spp.

Table 1 Mean number of conidia $\left(\times 10^{4} / \mathrm{ml}\right)$ from different Neonectria ditissima isolates produced in vitro on water agar (WA) and apple sap-amended water agar (ASAWA) media. The isolates had been taken from apple trees in various regions of New Zealand.

\begin{tabular}{lccccc}
\hline & & & & \multicolumn{2}{c}{ No. conidia } \\
\cline { 5 - 6 } Isolates & Cultivar & Region & isolated & ASAWA & WA \\
\hline ICMP 13255 & Unknown & Auckland & 1997 & 0 & 0 \\
ICMP 14415 & 'Royal Gala' & Waikato & 2000 & 5.75 & 1.81 \\
ICMP 9472 & Unknown & Pukekohe & 1987 & 45.31 & 6.25 \\
MW 12.1 & 'Scilate' & Motueka & 2013 & 40.25 & 15.31 \\
MW 15.1 & 'Scilate' & Motueka & 2013 & 28.44 & 12.62 \\
MW 18.1 & 'Scilate' & Motueka & 2013 & 41.94 & 8.88 \\
NA55 & 'Scilate' & Motueka & 2013 & 43.19 & 12.94 \\
NA56 & 'Scilate' & Motueka & 2013 & 32.75 & 5.88 \\
NA57 & 'Scilate' & Motueka & 2010 & 21.06 & 6.88 \\
NA90 & 'Braeburn' & Riwaka & 2013 & 46.81 & 11.88 \\
NA91 & 'Braeburn' & Riwaka & 2013 & 12.38 & 0.19 \\
NA92 & 'Braeburn' & Riwaka & 2013 & 31.56 & 8.81 \\
NA93 & RG-BR & Riwaka & 2013 & 32.06 & 3.81 \\
NA94 & RG-BR & Riwaka & 2013 & 34.5 & 13.56 \\
NA98 & RG-BR & Riwaka & 2013 & 38.38 & 11.31 \\
\hline Media effect & & & $30.29 \mathrm{a}^{1}$ & $8.01 \mathrm{~b}$ \\
\hline
\end{tabular}

${ }^{1}$ For media effect, values followed by the same letter are not significantly different at $\mathrm{P} \leq 0.05$ according to Fisher's protected LSD.

${ }^{2}$ RG-BR stands for advanced selection from 'Royal Gala'-'Braeburn' cross. 

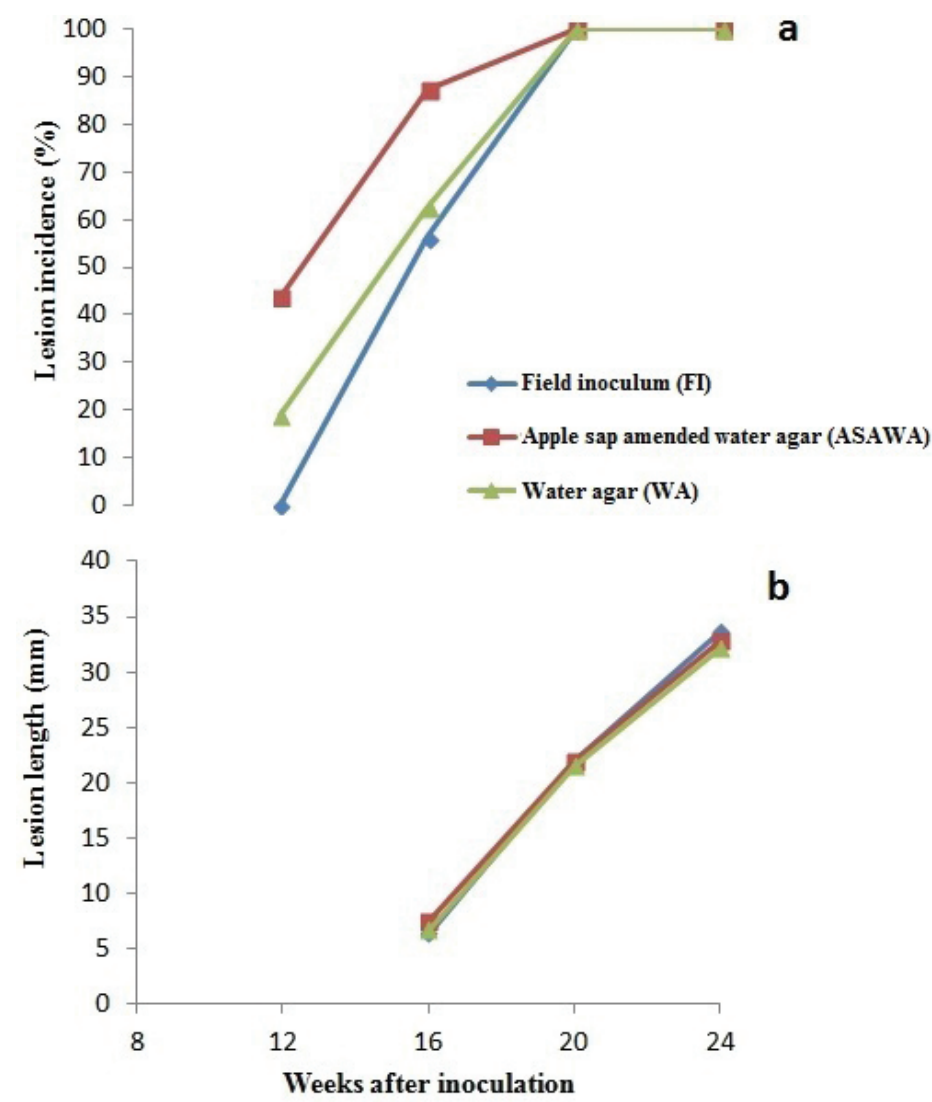

Figure 2 (a) canker incidence and (b) lesion lengths on rasp-wounds on apple shoots at 16-24 weeks after inoculation with Neonectria ditissima conidia produced from three different sources.

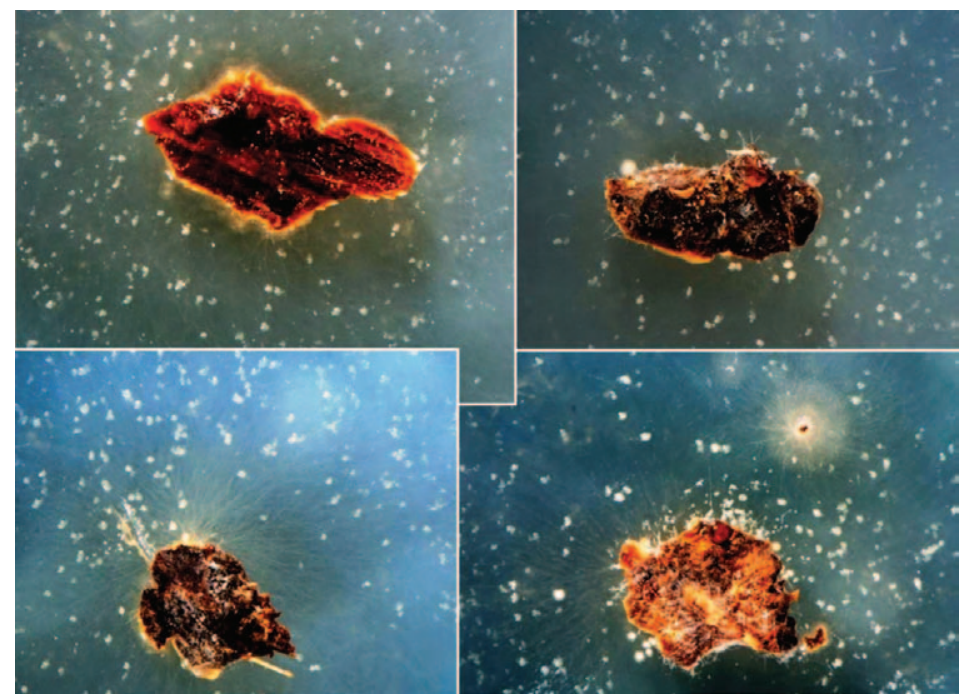

Figure 3 Excised woody apple tissue on sap amended water agar (ASAWA) with Neonectria ditissima sporodochia (white dots) formation on the surface of agar. 
Table 2 Mean percentage retrieval of Neonectria ditissima from woody tissues onto water agar (WA) or apple sap-amended water agar (ASAWA) at 2 weeks after incubation $(n=20$ pieces of tissue for each cultivar/medium combination).

\begin{tabular}{|c|c|c|c|c|}
\hline \multirow[b]{2}{*}{ Cultivar } & \multicolumn{2}{|c|}{ Symptomatic tissues } & \multicolumn{2}{|c|}{ Symptomless tissues } \\
\hline & ASAWA & WA & ASAWA & WA \\
\hline 'Scilate' & 50 & 30 & 20 & 0 \\
\hline 'Braeburn' & 20 & 20 & 0 & 0 \\
\hline 'Royal Gala' & 30 & 10 & 30 & 0 \\
\hline
\end{tabular}

\section{DISCUSSION}

In this study, the use of water agar, either alone or amended with apple sap extract, was very effective for isolation of $N$. ditissima from woody tissues. Sporodochia and conidia of $N$. ditissima were formed within 7-10 days, allowing confirmation of presence of the European canker pathogen. This method of isolation allowed $N$. ditissima to be isolated from symptomatic or asymptomatic woody tissues at any time of year. The isolation of $N$. ditissima onto high nutrient media invariably allowed many other faster growing fungal colonies to emerge, and those fungi suppressed all slow-growing fungi, including $N$. ditissima. This observation was consistent with those of Brown et al. (1993), who also noted that the frequency of recovery of $N$. ditissima from typical canker symptoms was greatly reduced by the presence of endophytic fungi and other species closely related to $N$. ditissima growing within the woody tissues. To overcome this problem, Anagnostakis \& Ferrandino (1998) inserted small pieces of cankered bark into 'Granny Smith' apples and, after incubation in the laboratory, isolated pure cultures of $N$. galligena by peeling away the skin and placing the discoloured tissue onto PDA. However, these isolations also usually yielded bacteria or rapidly growing fungi, including Pestalotiopsis. This problem was never observed in the present study when isolations were made onto ASAWA or WA.

The use of ASAWA was more suitable than use of WA for producing high numbers of conidia for infection studies. When using different brands of water agars (data not shown), it was found that only the water agar medium prepared from
Fisher Scientific agar yielded sporodochia and conidia. The inability of isolate ICMP 13255 to sporulate is considered to be due to repeated sub-culturing. This conclusion is consistent with the experience of Amponsah et al. (2008), who observed that Neofusiccocum and Diplodia species lost their ability to sporulate after repeated sub-culturing, irrespective of medium type and incubation conditions. This observation has also been recorded by other researchers (Sloan et al. 1960; Shahin \& Shepard 1979). Moreover, not all $N$. ditissima isolates yielded sporodochia in culture even immediately after isolation from plant tissue. The production and release of $N$. ditissima conidia relies on rainfall (Latorre et al. 2002), and therefore infection studies require harvesting of conidia from field-infected orchards after wet days. Moreover, incubation of infected canker tissues to induce the production of sporodochia and conidia is not always possible and in many instances only a few conidia may be produced.

This study has described an agar culture method that can be used to produce $N$. ditissima conidia in vitro reliably and on demand for use in infection studies. The conidia produced in this way were equally as pathogenic as those obtained from the field, and the conidia produced on ASAWA or WA resulted in faster development of disease symptoms compared to field-collected conidia, being visible as soon as 12 weeks after inoculation. This method for production of $N$. ditissima conidia in vitro will be particularly useful for European canker resistance research, as conidia can be produced at any time of the year and without the risk of spores of other species contaminating the inoculum. 


\section{ACKNOWLEDGEMENTS}

This study was conducted with financial support from the Agricultural and Marketing Research Development Trust (AgMARDT). We thank Drs Robert Beresford and Ian Horner for reviewing a draft of this paper.

\section{REFERENCES}

Amponsah NT, Jones EE, Ridgway HJ, Jaspers MV 2008. Production of Botryosphaeria species conidia using grapevine green shoots. New Zealand Plant Protection 61: 301-305.

Anagnostakis SL, Ferrandino FJ 1998. Isolation of Nectria galligena from cankers on sweet birch. Plant Disease 82:440-441.

Beresford RM, Kim KS 2011. Identification of regional climatic conditions favorable for development of European canker of apple. Phytopathology 101: 135-146.

Brown AE, Muthumeenaski S, Sreenivasaprasad S, Mills PR, Swinburne TR 1993. A PCR primer specific for Cylindrocarpon heteronema for detection of the pathogen in apple wood. FEMS Microbiology Letters 108: 117-120.
Latorre BA, Rioja ME, Lillo C, Munoz M 2002. The effect of temperature and wetness duration on infection and a warning system for European canker (Nectria galligena) of apple in Chile. Crop Protection 21(4): 285-291.

McCracken AR, Berrie AM, Barbara DJ, Locke T, Cooke LW, Phelps K, Swinburne TR, Brown AE, Ellerker B, Langrell SRH 2003. Relative significance of nursery infections and orchard inoculum in the development and spread of apple canker (Nectria galligena) in young orchards. Plant Pathology 52: 553-566.

Shahin EA, Shepard JF 1979. An efficient technique for inducing profuse sporulation of Alternaria species. Phytopathology 69: 618-620.

Sloan BJ, Routien JB, Miller VP 1960. Increased sporulation in fungi. Mycologia 52: 47-63. 